\title{
THE
}

\section{Nonprescription Naloxone: Pros and Cons}

Karen M S Bastianelli

Kelly Orr

University of Rhode Island, kellyo@uri.edu

Follow this and additional works at: https://digitalcommons.uri.edu/php_facpubs

The University of Rhode Island Faculty have made this article openly available.

Please let us know how Open Access to this research benefits you.

This is a pre-publication author manuscript of the final, published article.

Terms of Use

This article is made available under the terms and conditions applicable towards Open Access

Policy Articles, as set forth in our Terms of Use.

\section{Citation/Publisher Attribution}

Bastianelli, K. M. S. \& Orr, K. K. (2014). Nonprescription naloxone: Pros and cons. Journal of American Pharmacists Association, 54(4), 328-329. doi: 10.1331/JAPhA.2014.14048

Available at: http://dx.doi.org/10.1331/JAPhA.2014.14048 


\section{Title: The Case for Nonprescription Naloxone?}

\section{$\underline{\text { Authors }}$}

Karen M.S. Bastianelli, PharmD, BCACP Assistant Professor, University of Minnesota-College of Pharmacy, Duluth; and

Katherine Kelly Orr, PharmD, Clinical Associate Professor, The University of Rhode Island College of Pharmacy;

Address correspondence to:

Email address: bast0067@d.umn.edu

Word count: 647; References: 9;

Key Words: naloxone, nonprescription medication, over-the-counter 
Drug overdose deaths increased for the 11th consecutive year causing 38,329 deaths in the United States in 2010, with nearly 60 percent of the those deaths $(22,134)$ involving pharmaceutical drugs. Opioid analgesics, such as oxycodone, hydrocodone, and methadone, were involved in about 3 of every 4 pharmaceutical overdose deaths $(16,651)$, confirming the predominant role opioid analgesics play in drug overdose deaths according to an analysis from the CDC released in February 2013. ${ }^{1}$

This trend continues to grow, despite opioid harm reduction strategies such as medication formulations that decrease methods of abuse, education initiatives (such as www.AwareRX.org, founded in Minnesota), public medication take-back events, proper prescribing initiatives, and state-run Prescription Drug Monitoring Programs. When these efforts fail to prevent an overdose, a proven avenue to reduce morbidity and mortality is the use of naloxone, a pure opioid antagonist. Injectable naloxone has been available in the US for more than 40 years and is a standard rescue medication carried by emergency medical services (EMS). Some EMS programs have further developed a system to administer the injectable formulation intranasally via a marketed atomizer/nebulizer device, thereby decreasing concerns of transferring blood borne pathogens. $^{2}$

Rescue strategies are needed that reach beyond emergency response systems, thus becoming more accessible to the general public. Although programs of distribution continue to expand across the country, nineteen $(76.0 \%)$ of the 25 states with 2008 drug overdose death rates higher than the median and nine $(69.2 \%)$ of the 13 states in the highest quartile did not have a community-based opioid overdose prevention program that distributed naloxone. ${ }^{3}$ Proper education and training is essential as the potential benefits of naloxone are temporary; 
consequently, all users are instructed to call for emergency assistance as part of standard protocols. As highlighted in a recent article by Bailey et. al., community-based pharmacy practitioners have worked toward overcoming logistic and cultural barriers to make naloxone distribution for overdose a standard and acceptable practice. ${ }^{4}$

Despite the increased recognition to improve access, some safety and ethical concerns have been raised in previous debates on expanded use of the medication. Health professionals have noted fatalities may result, especially if used by untrained people, and perhaps naloxone use may increase avoidance of contacting EMS. ${ }^{4-6}$ Though due to naloxone's short-half life, it is critical to receive additional medical services after the antidote is administered as further "reversal" may be warranted. ${ }^{6}$ Another major obstacle has been that many states do not include naloxone as part "Good Samaritan” regulations protecting against legal implications when tending to persons in need of emergency aid. ${ }^{4}$

In April of 2012, the FDA, the Center for Drug Evaluation and Research, the Office of the Assistant Secretary for Health, National Institutes of Drug Abuse, and the Centers for Disease Control and Prevention (CDC) sponsored a public discussion on the potential value of making naloxone more widely available to reduce the incidence of opioid overdose fatalities. The majority of individuals participating in the program were in support of an over-the-counter (OTC) approval of naloxone. However, several steps must occur to facilitate an OTC switch. An intranasal (or auto - injector) formulation would require bioequivalence studies since this current delivery form is off - label, as well as data to support safety, chemistry, and manufacturing. An OTC switch would also require usage studies to ensure patients or caregivers can understand directions and determine if product use is appropriate for them. ${ }^{5}$ 
Pros and cons exist for an OTC naloxone. Impact from an OTC version will greatly increase the availability of naloxone; therefore, possibly saving thousands of lives if used correctly. Conversely, misuse of the product could result in deaths through lack of patient education and failure to contact EMS. Pharmacists play a critical role in the appropriate use of nonprescription medications in self-care and this may be an optimal product to be considered with the Nonprescription Safe Use Regulatory Expansion (NSURE) Initiative requiring a consult with the pharmacist prior to sale. ${ }^{9}$

1. CDC. Opioids drive continued increase in drug overdose deaths; 2/20/13 CDC press release, http://www.cdc.gov/media/releases/2013/p0220_drug_overdose_deaths.html. Accessed February 24, 2014.

2. Wermeling D. A response to the opioid overdose epidemic: Naloxone Spray http://www.ncbi.nlm.nih.gov/pmc/articles/PMC3668569/, accessed 3/12/14

3. CDC. Community-Based Opioid Overdose Prevention Programs Providing Naloxone United States, 2010. MMWR, February 17, 2012, http://www.cdc.gov/mmwr/preview/mmwrhtml/mm6106a1.htm?s_cid=mm6106a1_w Accessed 3/12/14

4. Bailey AM, Wermeling DP. Naloxone for opioid overdose prevention: Pharmacists' role in community-based practice settings. Ann Pharmacother. 2014 Feb 12. [Epub ahead of print]

5. Role of naloxone in opioid overdose fatality prevention; Post meeting summary; Public workshop, U.S. Food and Drug Administration, U.S. Department of Health and Human 
Services.http://www.fda.gov/downloads/Drugs/NewsEvents/UCM318909.pdf. Accessed March 3, 2014.

6. Byrne A. Emergency naloxone for heroin overdose: over the counter availability needs careful consideration. BMJ. 2006;333(7571):754.

7. Andree RA. Sudden death following naloxone administration. Anesth Analg. 1980;59:782-4.

8. Ashworth A. Beware of naloxone's other characteristics. BMJ. 2006;333(7571):754.

9. US Food and Drug Administration, US Department of Health and Human Services. Using innovative technologies and other conditions of safe use to expand which drug products can be considered nonprescription. Public hearing. Fed Regist. 2012;77(39):12059-12062. 